\title{
The cuckoo wrasse, Labrus mixtus (Pisces: Labridae): biological indices for life history and conservation
}

\author{
SANJA MATIĆ-SKOKO, DUBRAVKA BOJANIĆ VAREZIĆ, JASNA ŠILJIĆ, \\ PERO TUTMAN and ARMIN PALLAORO \\ Institute of Oceanography and Fisheries, PO Box 500, Šetalište Ivana Meštrovića 63, 21000 Split, Croatia. \\ E-mail: dbojanic@izor.hr
}

\begin{abstract}
SUMMARY: The cuckoo wrasse, Labrus mixtus, is widely distributed in the moderate warm waters of the Atlantic Ocean, including the Mediterranean and Adriatic Seas. Generally, labrids are small inshore coastal species susceptible to anthropogenic habitat degradation and, although without commercial importance, they make up a significant part of the by-catch and discard. Also, these fishes are intensively caught in recreational and subsistence fisheries. Basic biological information is required for their stock assessment and conservation. Studies of the age, growth, reproduction and feeding of $L$. mixtus have not been undertaken previously in the Adriatic Sea. The observed maximum age of the cuckoo wrasse was 10 years, although most of the sampled fish were 7 years old. The estimated parameters of the von Bertalanffy growth model suggested that the growth of L. mixtus was relatively fast in the first four years of life. L. mixtus is a protogynous hermaphrodite and sex change occurred at $26 \mathrm{~cm}$, while the greatest increase in gonadosomatic index in April confirmed spring as the spawning period. The cuckoo wrasse is an opportunistic predator, feeding primarily on crustaceans, gastropods and fishes. The information provided on biological indices is necessary for life history pathways and future conservation measures of this population in the Adriatic Sea.
\end{abstract}

Keywords: Labrus mixtus, Adriatic Sea, age, growth, diet, protogynous hermaphrodite.

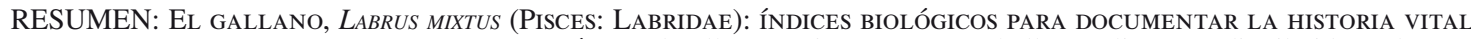
DE LA ESPECIE Y CONTRIBUIR A SU CONSERVACIÓN. - El gallano, Labrus mixtus, se halla ampliamente distribuido en las zonas templadas del Océano Atlántico, incluyendo el Mediterráneo y el Mar Negro. En general, los lábridos son especies de pequeño tamaño que habitan en aguas costeras, siendo vulnerables a la degradación antrópica del hábitat y, a pesar de ser comercialmente poco importantes, forman una parte importante de los descartes de la pesca profesional. Estos peces también son intensamente capturados por la pesca recreativa o de subsistencia. Se requiere, pues, una información biológica básica para conocer el estado de los stocks y asegurar su conservación. Los estudios sobre la edad, el crecimiento, la reproducción y la alimentación de L. mixtus no se han realizado hasta ahora en el Adriático. La edad máxima observada en esta especie ha sido de 10 años, si bien la mayoría de los peces capturados se situaba en los 7 años. Los parámetros estimados a partir de la ecuación de crecimiento de Von Bertalanffy sugieren que el crecimiento de $L$. mixtus es rápido durante los primeros años de vida. L. mixtus es una especie hermafrodita proterogínica y el cambio de sexo se produce a los $26 \mathrm{~cm}$ de longitud, mientras que el gran incremento del índice gonadosomático en el mes de abril confirma que el periodo de reproducción se produce durante la primavera. El gallano es un depredador oportunista que se alimenta preferentemente de crustáceos, gasterópodos y peces. La información que se da en este artículo sobre los índices biológicos es necesaria para conocer las características vitales de esta especie y para adoptar futuras medidas de conservación de su población en el Adriático.

Palabras clave: Labrus mixtus, Adriático, edad, crecimiento, alimentación, hermafrodita proterogínica.

\section{INTRODUCTION}

The family Labridae (wrasses) contains 18 species native to the Adriatic Sea. In terms of their habitat, Mediterranean wrasses are generally fairly shallow- water, demersal, inshore coastal species, generally sedentary in macroalga-dominated rocky reef habitats, but some also occur in seagrass beds (Bell and HarmelinVivien 1982) and in coastal lagoons, and a few extend to deeper-water coralligenous habitats. Primarily due 
to their small size, they are generally not heavily targeted. But they are intensively caught in recreational fisheries and they make up a significant percentage in the by-catch and discard of local artisanal and subsistence fisheries (Cetinić et al. 2011, Tzanatos et al. 2007). Such fisheries involve large numbers of people and consequently high levels of fishing effort (Cowx 2002, Pitcher and Hollingworth 2002, Westera et al. 2003). Without doubt, commercial and recreational fishing have similar demographic and ecological effects on fished populations, and they can have equally serious ecological and economic consequences (Coleman et al. 2004). In the Adriatic, as well as in the Mediterranean, recreational fishing has always been important, representing at present more than $10 \%$ of total fisheries production in the area (EU 2004). However, despite the importance, only a few studies have focused on the Mediterranean recreational fisheries. Scientists and fisheries experts are in full agreement that the actual number of people involved and the yields are still unknown and that a significant number of recreational anglers are not official license-holders. Members of the family Labridae mainly inhabit coastal habitats, and are therefore more sensitive to anthropogenic degradation and water pollution. However, according to the Red List Criteria, most of them, as well as the species dealt with herein, are assessed as Least Concern. We can assume that the main reason is poor exploration of these species because of their economic irrelevance. Thus, all of them suffer from relatively poor fisheries and conservation management, though most are included in some form of marine protection in the region (Jardas et al. 2008).

The cuckoo wrasse, Labrus mixtus (Linnaeus 1758 ), is found on rocky reefs covered by algae or in seagrass (Posidonia oceanica) meadows (Muus and Nielsen 1999), usually solitary or in pairs with young, at depths ranging from 15 to $40 \mathrm{~m}$ (Jardas 1996). It can also inhabit coralligenous bottoms at depths of 20-100 m (Gomon and Forsyth 1990). It occurs in the whole Mediterranean, except the Black Sea, and in the eastern Atlantic from Norway to Senegal (Jardas 1996). It is a non-migratory fish, which can inhabit the same area during most of its lifetime (Gomon and Forsyth 1990). It is a protogynous hermaphrodite and the change of sex is completed within a period of about seven months (Quignard and Pras 1986). Cuckoo wrasse becomes mature in the second year of life, with a total length of around $16 \mathrm{~cm}$, and spawns in April and May (Jardas 1996). The females have the ability to change sex when there are no males present in the area (Dipper and Pullin 1979). Females lay about 1000 eggs in a nest of algae guarded by the males (Muus and Nielsen 1999). The literature suggests that it is an obligatory carnivorous feeder, preying mostly on crabs, followed by smaller fishes and molluscs (Quignard and Pras 1986), and worms (Quignard and Pras 1986, Muus and Nielsen 1999). However, little is known about how the diet of L. mixtus is affected by size, sex or season. This species is of very little commercial value along the Croatian coast. In the landing statistics for the eastern Adriatic, catches for L. mixtus are estimated at 1 ton per year (Jardas 1996).

Although the biology and ecology of tropical labrids have been studied extensively, little is known about the biological indices of Mediterranean labrid species, particularly of $L$. mixtus. This species was previously known as Labrus bimaculatus Linnaeus, 1758. Considering the long use of this synonym in the past and the fact that the species is not well researched, determination of the current ecological and fishery status of the species may be further complicated. Somewhat more detailed literature is available on growth, reproductive behaviour and population distributions of other Mediterranean labrids (Warner and Lejeune 1985, Cardinale et al. 1998, Guidetti 2000, Pallaoro and Jardas 2003, Škeljo et al. 2012). It is very important to know life histories of small littoral fishes in coastal fisheries using an environmental and functional approach. Small, non-commercial but abundant littoral fish tend to play an important role in the functioning of ecosystems (Choat and Bellwood 1998, Nelson 1994, Wainwright and Bellwood 2002) and it is therefore extremely important to determine their life history parameters (Pauly et al. 2002), to consider their importance and to assess the possible threat to them of anthropogenic impacts through intensive artisanal fishing, climate change and pollution (Stagličić et al. 2011). Therefore, the present study was conducted to obtain more information on biological indices of L. mixtus, to give a broader framework of the parameters required for the life history tools, and to establish the basis for fisheries and conservation management in the Adriatic and Mediterranean.

\section{MATERIALS AND METHODS}

A total of 197 individuals of Labrus mixtus were caught with angle, bottom long-line and trammel net in the eastern central Adriatic, Vis Archipelago (Fig. 1), from 30 to $65 \mathrm{~m}$ depths. Samples were taken monthly from April to December 2009 from subsistence fisherman landings. During the winter months, it was not possible to collect this species.

For each fish, the total length (TL) was measured $(0.1 \mathrm{~cm})$, the total body weight $(\mathrm{W})$ was recorded $(0.1$ $\mathrm{g}$ ), and the sagittal otoliths were removed, cleaned and stored dry for further examination. Sex was determined by direct visual observation of the gonads' appearance. Individuals with male and female gonads were classified as a transitional form (Moe 1969, Smith 1965). For the estimation of length at $50 \%$ maturity $\left(\mathrm{L}_{50}\right)$, a percentage of the mature females and males by size class was used (Tsikliras et al. 2013). This ratio is fitted to a logistic equation calculated by the following formula: $\mathrm{P}=\mathrm{a} /\left(1+\left(((\mathrm{a}-\mathrm{b}) / \mathrm{b}) *\left(\mathrm{e}^{-\mathrm{c}^{*} \mathrm{~L}}\right)\right)\right)$, where $\mathrm{a}, \mathrm{b}$ and $\mathrm{c}$ are constants (Saila et al. 1988). Statistica for Windows 8.0 (StatSoft Inc. 2007) was used to calculate the predicted 


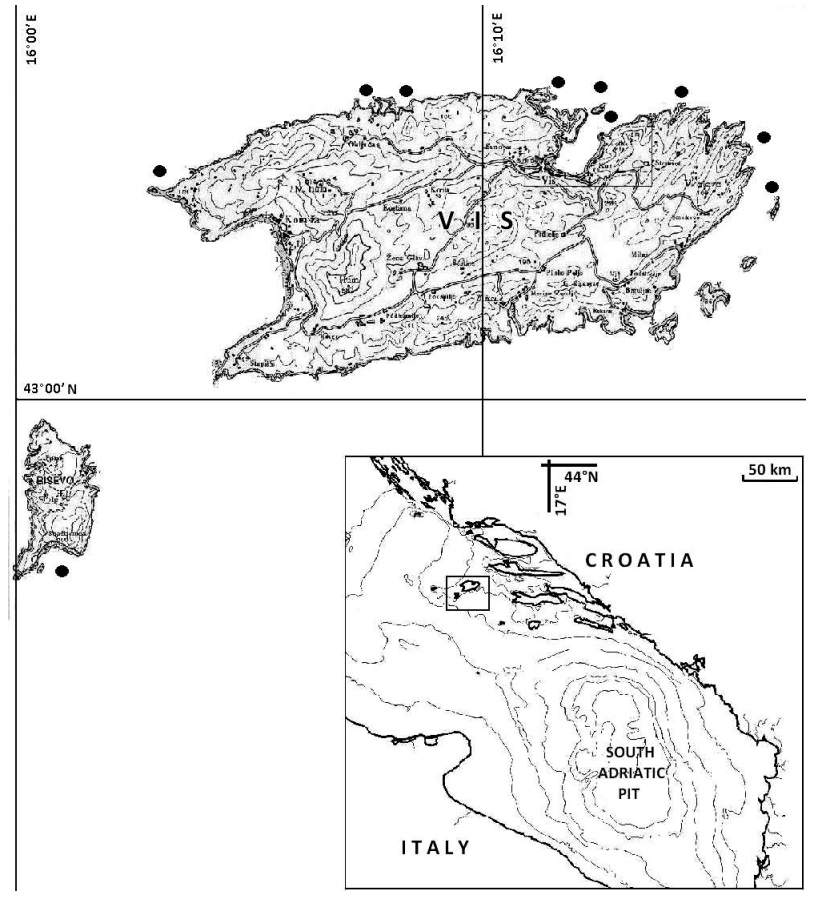

FIG. 1. - The study area in the central Adriatic Sea with sampling locations around Vis Archipelago.

values and the coefficients. The gonadosomatic index was calculated as GSI $=(\mathrm{Wg} / \mathrm{W}) * 100$, where $\mathrm{Wg}$ is the gonad weight. For testing the sex ratio a simple chisquare test was used. The size frequency distributions (1-cm length classes) between sexes are determined. All data were tested for normality and homogeneity of variances.

The length-weight relationship was described by the equation $\mathrm{W}=\mathrm{aTL}^{\mathrm{b}}$ (Ricker 1975). The variation in $\mathrm{b}$ value from 3 was tested by the one sample t-test. Analysis of covariance (ANCOVA) was used to test the differences in size-weight relationship between the sexes, considering fish length as a covariate. The condition factor was calculated from the equation: $\log$ $\mathrm{W}=\mathrm{b} \log \mathrm{TL}+\log$ a (Ricker 1975).

The age was determined by interpreting the growth rings on the otoliths. Otoliths were fastened to a slide and then sanded using 30- $\mu$ sand paper to facilitate the observation of the opaque and translucent zones. All otoliths were observed immersed in water against a black background using a stereo microscope at the 20 magnification. Age was determined by counting growth rings on the posterior otolith region. All otoliths were read independently by three experienced researchers, with age being assigned when at least two of the readers were in agreement. The index of average percent error (Beamish and Fournier 1981) and the mean coefficient of variation (Chang 1982) were calculated to estimate the relative precision between readings. Low values of the indices indicated a good precision of age estimation.

The sample available for age and growth studies consisted of 87 individuals (93.1\% readable otoliths).
A ring mark was considered as the outer edge of the opaque zone. Opaque and translucent zones exhibited an alternating pattern. The total number of translucent zones was recorded in order to assign an estimated age to the specimens. The periodicity of opaque zone formation was examined by the edge-type analysis (Palazón-Fernandez et al. 2010). The marginal edge of each otolith was examined and classified as opaque or translucent and percentages of otoliths with opaque and translucent margins were plotted by month of capture in order to locate periodical trends in the zone formation.

Length-at-age was described by the von Bertalanffy growth function (VBGF) $\mathrm{TL}=\mathrm{L}_{\infty}\left(1-\mathrm{e}^{-\mathrm{k}\left(\mathrm{t}-\mathrm{t}_{0}\right)}\right)$, where TL is total length-at-age $t, L_{\infty}$ is asymptotic length, $k$ is the body growth coefficient and $\mathrm{t}_{0}$ is theoretical age at zero length (Beverton and Holt 1957). The von Bertalanffy growth parameters were estimated using a nonlinear least square procedure, through a Gauss-Newton algorithm. The multivariate Hotelling's $\mathrm{T}^{2}$-test was used to compare growth parameters obtained for males and females. The Kolmogorov-Smirnov two-sample test was used to analyse both age and size frequency distributions of both sexes. The mean lengths of males and females in the same age classes were tested using a $\mathrm{t}$-test. Prior to using the t-test, the data were tested for normality (Kolmogorov-Smirnov test of normality). Taylor's (1960) equation (year when fish reach 95\% of $\mathrm{L}_{\infty}$ ) was used to calculate longevity from parameters obtained by the VBGF, $A_{0.95}=[2.9957 / \mathrm{k}]+\mathrm{t}_{0}$, where $\mathrm{A}_{0.95}$ is the lifespan or age required to reach $95 \%$ of the final length $\left(\mathrm{L}_{\infty}\right)$, and $\mathrm{t}_{0}$ and $k$ are von Bertalanffy growth parameters in term of confirming that obtained age from otolith reading are realistic.

In order to evaluate differences in food habits with respect to size, fish were separated into four size classes $(<22,22-25,25-28,>28 \mathrm{~cm})$. The complete digestive tubes were weighed (wet weight) and preserved in $4 \%$ formaldehyde for the examination of their contents. Afterwards, in the laboratory, gut contents were identified and the number of empty stomachs was shown as the vacuity index (\%VI). Stomach contents were examined in the laboratory under a dissecting microscope using reflected light and each dietary item was identified to the lowest possible taxon. Level of identification depended on the completeness of the food organism and its condition.

The qualitative analysis of food structure is the overall list of determinable taxa (Table 1). Quantitative analysis is presented using three standard indices: frequency of occurrence $(\% \mathrm{~F})$, numerical percentage $(\% \mathrm{~N})$ and gravimetric percentage $(\% \mathrm{~W})$ (Hyslop 1980). To get more precise results of diet we used the index of relative importance (\%IRI) (Pinkas et al. 1971). The statistical differences in the diet among fish sex, size and seasons were tested with a one-way analysis of similarity (ANOSIM). A similarity percentage analysis (SIMPER) was used to determine which prey groups were responsible for differences between 
TABLE 1. - Labrus mixtus. Length-at-age data for cuckoo wrasse from the Adriatic Sea aged using otolith readings. Figures show the number of individuals classed by age within each length interval. N, total number of individuals; TL, total length; W, total weight.

\begin{tabular}{|c|c|c|c|c|c|c|c|c|}
\hline $\mathrm{TL}(\mathrm{cm})$ & 3 & 4 & 5 & $\underset{6}{\operatorname{Age}(y r)}$ & 7 & 8 & 9 & 10 \\
\hline $16.6-17.5$ & 2 & & & & & & & \\
\hline $17.6-18.5$ & 2 & & & & & & & \\
\hline 18.6-19.5 & & 2 & & & & & & \\
\hline $19.6-20.5$ & 2 & 2 & & & & & & \\
\hline $20.6-21.5$ & 3 & 2 & & & & & & \\
\hline $21.6-22.5$ & & 3 & 1 & & & & & \\
\hline $22.6-23.5$ & & 1 & 9 & & & & & \\
\hline $23.6-24.5$ & & 2 & 5 & 2 & & & & \\
\hline $24.6-25.5$ & & & 1 & 5 & 2 & & & \\
\hline $25.6-26.5$ & & & & & 4 & & & \\
\hline $26.6-27.5$ & & & & 2 & 3 & 1 & & \\
\hline $27.6-28.5$ & & & & & 5 & 1 & & \\
\hline $28.6-29.5$ & & & & & 2 & & & \\
\hline $29.6-30.5$ & & & & & 3 & 4 & 2 & 1 \\
\hline $30.6-31.5$ & & & & & & 1 & 1 & \\
\hline $31.6-32.5$ & & & & & & 1 & & \\
\hline $32.6-33.5$ & & & & & & & 1 & 1 \\
\hline $33.6-34.5$ & & & & & & 1 & 1 & \\
\hline Total $(\mathrm{N})$ & 9 & 12 & 16 & 9 & 19 & 9 & 5 & 2 \\
\hline$\%$ & 11.1 & 14.8 & 19.7 & 11.1 & 23.5 & 11.1 & 6.2 & 2.5 \\
\hline Mean TL $(\mathrm{cm})$ & 19.2 & 21.3 & 23.4 & 25.4 & 27.5 & 30.3 & 31.7 & 31.8 \\
\hline SD TL & 1.5 & 1.5 & 0.7 & 1.0 & 1.5 & 1.9 & 1.7 & 1.3 \\
\hline Mean W (g) & 81.2 & 115.1 & 150.7 & 196.2 & 260.3 & 357.7 & 423.2 & 393.2 \\
\hline SD W & 22.7 & 26.8 & 21.9 & 24.9 & 61.6 & 82.0 & 89.8 & 82.9 \\
\hline
\end{tabular}

sex, size and season. Data were transformed to $\ln (x+1)$; the analysis is based on Bray-Curtis similarity, with 999 permutations used. This analysis was performed with the PRIMER 5 multivariate statistical package (v. 5.2.9; PRIMER-E Ltd) (Clarke and Warwick 2001).

\section{RESULTS}

A total of 197 individuals of Labrus mixtus were sampled, namely 107 females, 84 males and 6 transitional individuals. The male-female ratio for all fish combined was $0.79: 1.00$ and is not statistically different from the expected 1:1 ratio $(\mathrm{p}>0.05)$. The fish ranged from 13.0 to $38.2 \mathrm{~cm}$, with an average TL of $25.1 \mathrm{~cm}$ ( $\pm 4.2 \mathrm{SD})$, and from 28.7 to $744 \mathrm{~g}$, with an average $\mathrm{W}$ of $200.2 \mathrm{~g}( \pm 112.9 \mathrm{SD})$. The length frequency distribution of the total sample, males and females, exhibited mode at 25, 26 and $21 \mathrm{~cm}$, respectively (Fig. 2). Adult males ranged from 19.7 to $38.2 \mathrm{~cm}$, with an average TL of $27.1 \mathrm{~cm}( \pm 3.7 \mathrm{SD})$, while females ranged from 13.0 to $34.0 \mathrm{~cm}$, with an average TL of $23.4 \mathrm{~cm}( \pm 4.0$ SD). Length of the 6 transitional individuals ranged from 25.5 to $27.3 \mathrm{~cm}$, with an average TL of $26.2 \mathrm{~cm}$ $( \pm 0.6 \mathrm{SD})$. The size frequency distributions of males and females were significantly different (two-sample t-test, $\mathrm{p}<0.001)$.

The calculated length-weight equation for the whole sample was $\mathrm{W}=0.007 \mathrm{TL}^{3.116}\left(\mathrm{R}^{2}=0.885\right)$. This relationship for males was described by the parameters $\mathrm{a}=0.005$ and $\mathrm{b}=3.252\left(\mathrm{R}^{2}=0.890\right)$ and for females by the parameters $a=0.009$ and $b=3.052\left(R^{2}=0.870\right)$. The variations in $\mathrm{b}$ values from 3 were statistically significant for both males and females (t-test, $\mathrm{p}<0.001$ ). Analysis of covariance revealed significant differences between sexes (ANCOVA; p<0.05) (Fig. 3). The relative condition factor ranged from 0.52 to 2.21 for both sexes. There were significant mean differences among seasons (one-way ANOVA, $\mathrm{p}<0.05$ ), namely between summer and autumn (Tukey Test, $\mathrm{p}<0.05$ ). However, condition factor was the lowest in spring (Fig. 4). All specimens above $28 \mathrm{~cm}$ TL were sexually mature. The smallest female with an ovary containing ripe eggs had a total length of $13.0 \mathrm{~cm}$. The length of $50 \%$ maturity in females was estimated to be $15.23 \mathrm{~cm}$, while all females were mature at $19 \mathrm{~cm}$ TL. In males, the length of $50 \%$ maturity was at $25.2 \mathrm{~cm}$ and all males were mature at $29 \mathrm{~cm}$ TL (Fig. 5). The gonadosomatic index varied from 0.03 to 4.18 and did not differ significantly among seasons (one-way ANOVA, p>0.05) (Fig. 4). The gonadosomatic index varied from 0.15 to 4.18 for females, and from 0.03 to 0.26 for males.

Otoliths of Labrus mixtus displayed well-defined alternating opaque and translucent zones under reflected light (Fig. 6). The index of average percent error of ring counts for each reader did not differ greatly, and was slightly higher for the first author (2.72) than for the second (2.36) and third (2.48). The precision of the age estimates (coefficient of variation) was 1.2. The formation of growth increments followed a seasonal pattern (Fig. 7). The opaque zones are completely formed in summer. The proportion of otoliths with opaque margins was the highest $(>60 \%)$ in July, August and September. The translucent zones were laid down mainly in autumn-winter period, and these data suggest that one opaque and one translucent zone are laid down per year.

The age analysis revealed eight age classes and the presence of age groups 3-10. The oldest male of $L$. 


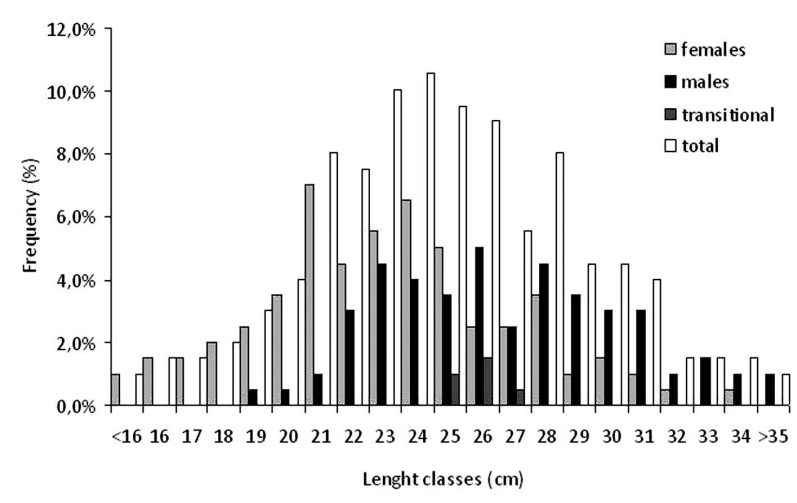

FIG. 2. - Frequency of females, males, transitional and total individuals within size classes of Labrus mixtus.

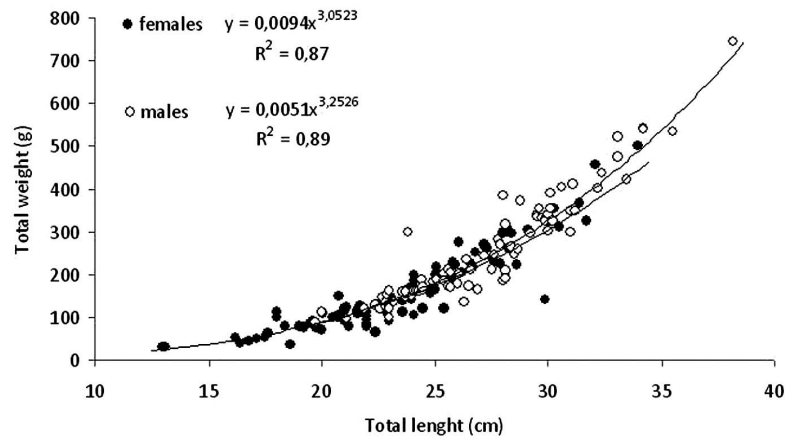

FIG. 3. - Length-weight relationship of Labrus mixtus sampled in the central Adriatic.

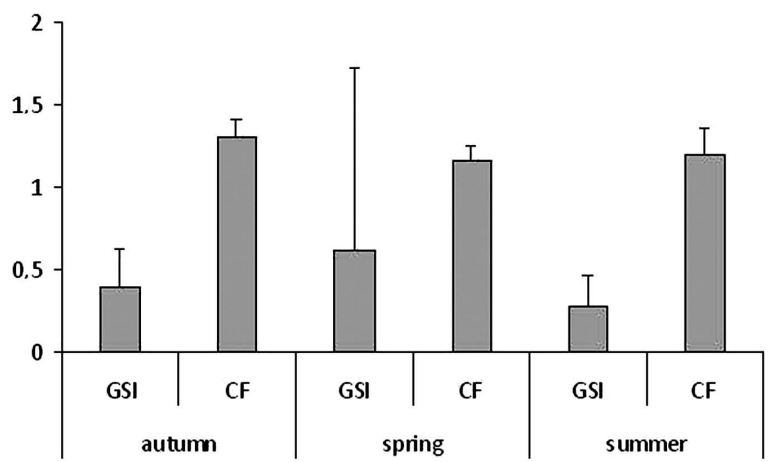

FIG. 4. - Seasonal variation of the gonadosomatic index (GSI) and relative condition factor $(\mathrm{CF})$ of Labrus mixtus from the Adriatic Sea.

mixtus was estimated to be 10 years old. Predominance of age classes $5^{+}$and $7^{+}$in the total catch $(43.2 \%$ individuals) was observed. There was some overlapping of individuals with the same lengths, especially for the individuals with higher TL. The pooled length-at-age data for L. mixtus is given in Table 1. Females were more numerous in the age classes $3^{+-} 7^{+}$, representing from $13.6 \%$ to $20.5 \%$. Males were the most numerous in $5^{+}$and $7^{+}$age classes represented by $24.3 \%$ and $27 \%$, respectively, and their number declined in all the next

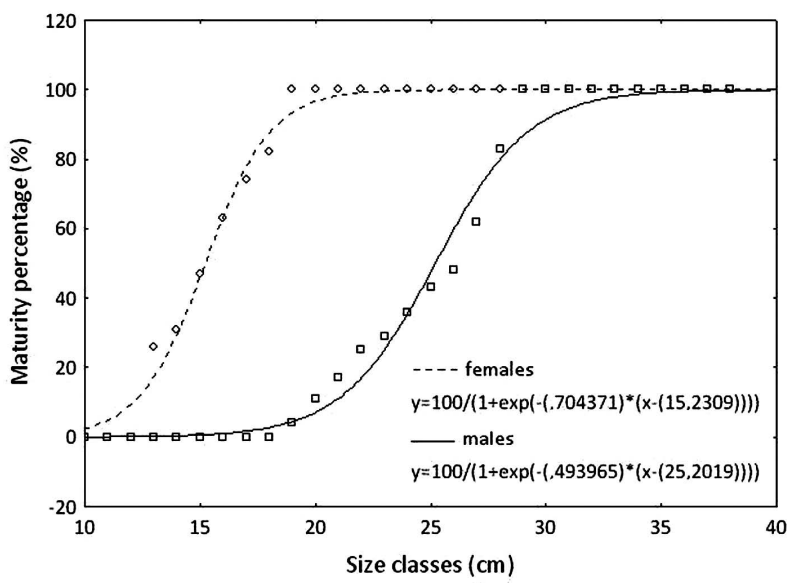

FIG. 5. - Sexual maturity ogive for females and males of Labrus mixtus in the Adriatic Sea.

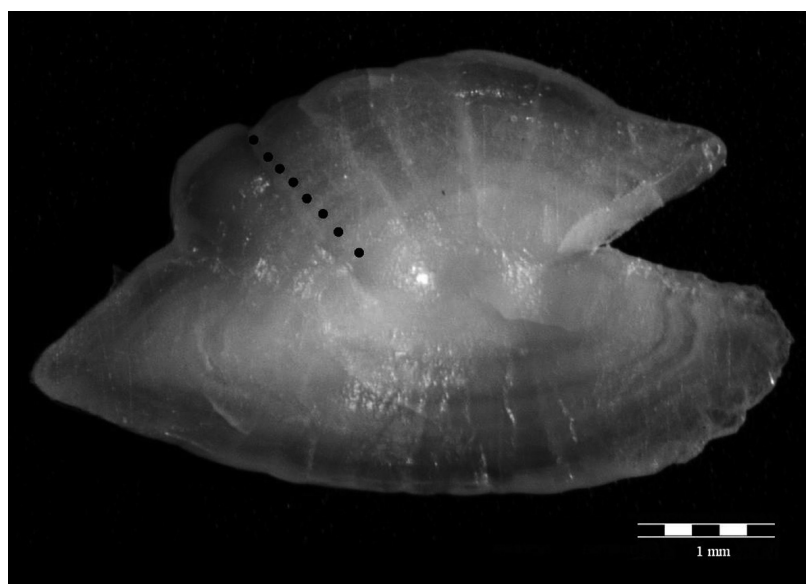

FIG. 6. - Sagittal otolith of the 8-year-old male Labrus mixtus, with $30.0 \mathrm{~cm}$ TL (Adriatic Sea).

classes. Age frequency distributions of L. mixtus are presented in Figure 8. The mean lengths at age of males and females showed that there were no significant differences for any of the age classes (two-sample t-test, $\mathrm{p}=0.868$ ). However, the age frequency distributions of males and females differed significantly (KolmogorovSmirnov two-sample test, $\mathrm{t}=-2.37$; $=0.02$ ).

The von Bertalanffy growth function (VBGF) for sampled population had the following parameters: $\mathrm{L}_{\infty}=34.2 \mathrm{~cm}(\mathrm{SE}=0.049), \mathrm{k}=0.224 \mathrm{yr}^{-1}(\mathrm{SE}=0.012)$ and $\mathrm{t}_{0}=-0.438 \mathrm{yr} \quad(\mathrm{SE}=0.277) \quad\left(\mathrm{R}^{2}=0.919\right)$. The non-linear least squares estimated parameters for the total sample, males and females are given in Table 2. Significant difference was found between the von Bertalanffy growth parameters of males and females, using a Hotelling's $\mathrm{T}^{2}$-test $\left(\mathrm{T}^{2}=45.89>\mathrm{T}_{0}{ }^{2}=12.52\right)$, with males growing at a slightly higher rate than females. According to the von Bertalanffy growth equation, obtained longevity $\left(\mathrm{A}_{0.95}\right)$ is estimated to 13 years. Furthermore, during the first four years of its life, growth of L. mixtus is intensive but afterwards its growth rate slows down considerably. 


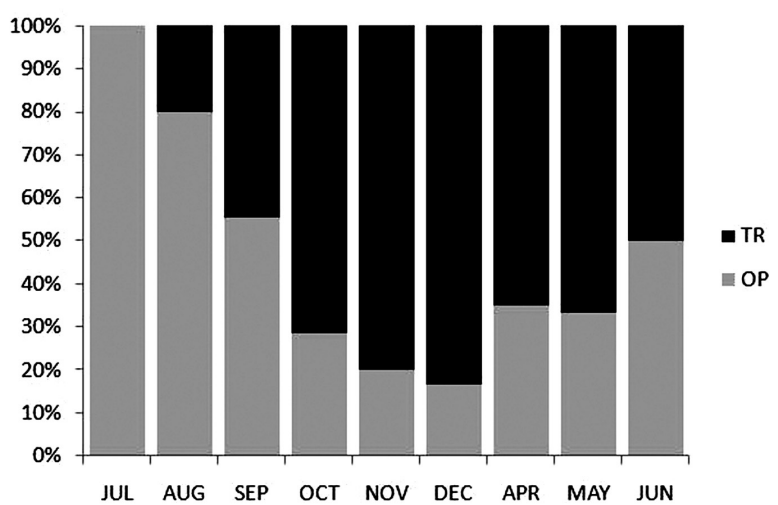

FIG. 7. - Annual variation pattern of the percentage of the opaque (OP) and translucent (TR) edges of Labrus mixtus otoliths sampled between April and December 2009.

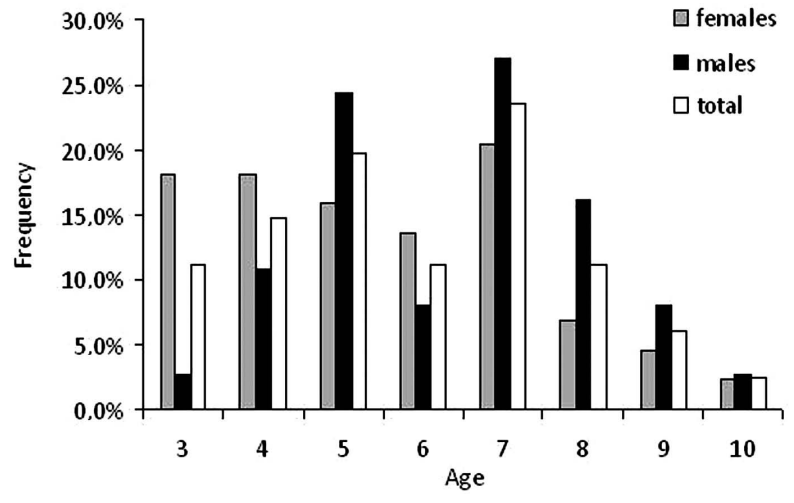

FIG. 8. - Age distributions of females, males and the total sample of Labrus mixtus from the Adriatic Sea.

Of the 87 stomachs analysed, 17 were totally or almost empty (\%VI=19.5). The total lengths of the fish examined ranged from 17.1 to $34.2 \mathrm{~cm}$. The proportion of empty stomachs did not vary significantly according to sex, size or season. However, increased numbers of empty stomachs in the smallest $(\% \mathrm{VI}=28 \%)$ and the greatest (\% VI $=24 \%)$ size class, as well as in the spring period $(\% \mathrm{VI}=29)$, was evident.

The diet of L. mixtus consisted of at least 60 different prey taxa belonging to 11 major groups (Crustacea, Gastropoda, Bivalvia, Scaphopoda, Pisces, Echinodermata, Polychaeta, Rotatoria, Bryozoa, Porifera and Algae). The relative importance of the different prey groups and taxa is given in the Table 3 . Crustacean have the highest index of relative importance $(\%$ IRI $=68.0)$ and they are the most frequent prey group $(\% \mathrm{~F}=67.1)$, so they can be regarded as the preferred food. The dominant prey species among crustaceans were Munida rugosa (\% IRI=3.5) and Scyllarus arctus (\%IRI=2.4), found in $7.1 \%$ and $4.3 \%$ of stomachs, respectively. Gastropods (\%IRI $=14.2$ ) occurred in $32.9 \%$ of the analysed specimens, and the most numerous species were Homalopoma sanguineum $(\mathrm{F} \%=8.6)$ and Turitella turbona $(\% \mathrm{~F}=7.1)$. Pisces (\% $\mathrm{IRI}=16.1)$ were found in $28.6 \%$ of stomachs, but they were in an
TABLE 2. - Growth parameters of all individuals, males and females, derived from the von Bertalanffy growth function of Labrus mixtus sampled in the eastern Adriatic Sea. All lengths are TL in $\mathrm{cm} \pm \mathrm{SE}$.

\begin{tabular}{lccc}
\hline Parameters & All data & Males & Females \\
\hline $\mathrm{L}_{\infty}(\mathrm{cm})$ & $34.20 \pm 0.049$ & $34.20 \pm 0.457$ & $33.90 \pm 0.271$ \\
$\mathrm{k}$ (per year) & $0.224 \pm 0.012$ & $0.234 \pm 0.020$ & $0.225 \pm 0.017$ \\
$\mathrm{t}_{0}$ (year) & $-0.438 \pm 0.277$ & $-0.237 \pm 0.491$ & $-0.484 \pm 0.369$ \\
\hline
\end{tabular}

advanced state of digestion and therefore could not be identified to the lower level. According to frequency of occurrence, gastropods and fishes can be considered as secondary food. All other prey groups are categorized as random food. Among them, the most commonly found preys are polychaetes $(\% \mathrm{~F}=8.6)$ and bivalves $(\% \mathrm{~F}=7.1)$.

The relationship between size classes and mean prey weight reveals a high exponential correlation $\left(\mathrm{R}^{2}=0.965\right)$ (Fig. 9A). The analysis of the mean number of prey per size class showed a power correlation $\left(\mathrm{R}^{2}=0.724\right)$, with the highest values concentrated in the fishes with a TL between 25 and $28 \mathrm{~cm}$ (Fig. 9B). The dietary preferences among the sex and seasons did not differ statistically but the similarity percentage analysis of the food spectrum showed a slightly higher level of diversity in males and, according to season, in early summer (Fig. 10A, B). Due to the positive correlation between the mean prey weight and the fish size, a significant difference among size classes was to be expected $(\mathrm{R}=0.056, \mathrm{p}<0.05)$ (Fig. 10C). According to SIMPER analysis, higher diversity is determined in

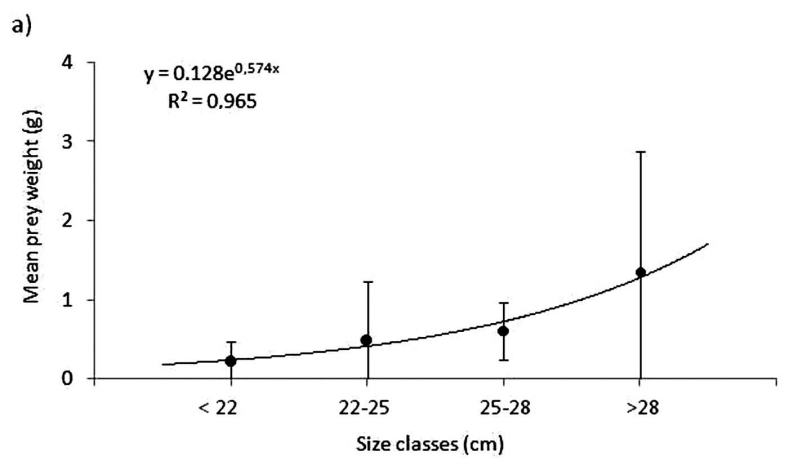

b)

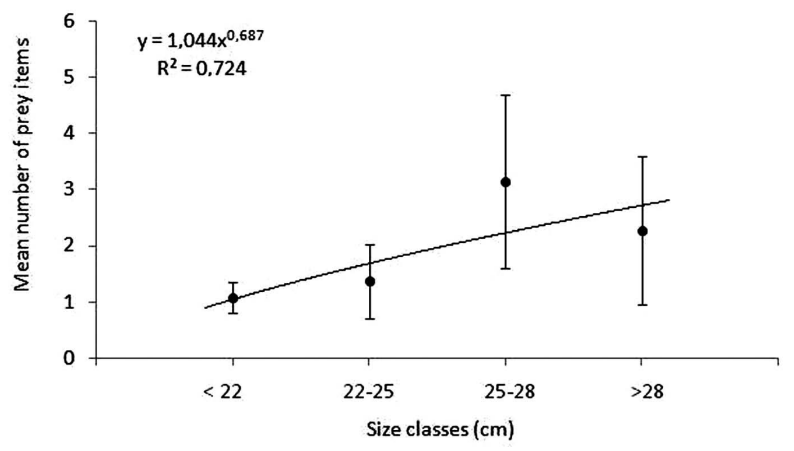

FIG. 9. - Relationship between Labrus mixtus size classes and (A) mean prey weight \pm standard deviation; (B) mean number of prey items \pm standard deviation. 
TABle 3. - Labrus mixtus. Percent frequency of occurrence $(\% \mathrm{~F})$, percent of total number $(\% \mathrm{~N})$, percent of total weight (\%W) and percent index of relative importance (\%IRI) for food items. (+) indicates all values $<0.1 \%$.

\begin{tabular}{|c|c|c|c|c|c|c|c|}
\hline \multicolumn{4}{|l|}{ Food items } & \multirow{2}{*}{$\begin{array}{l}\mathrm{F} \% \\
67.1\end{array}$} & \multirow{2}{*}{$\frac{\mathrm{N} \%}{40.1}$} & \multirow{2}{*}{$\frac{\mathrm{W} \%}{48.1}$} & \multirow{2}{*}{$\frac{\text { IRI } \%}{68.0}$} \\
\hline Crustacea & & & & & & & \\
\hline \multirow{21}{*}{ Decapoda } & Natania & & Non-identified Natania & 2.9 & 1.4 & 1.7 & 0.4 \\
\hline & Eucarida & Galatheidae & Galathea squamiffera & 2.9 & 1.4 & 1.6 & 0.4 \\
\hline & & & Galathea strigosa & 1.4 & 0.7 & 0.5 & 0.1 \\
\hline & & & Munida rugosa & 7.1 & 3.4 & 8 & 3.5 \\
\hline & & & Non-identified Galatheidae & 1.4 & 0.7 & 1.3 & 0.1 \\
\hline & & Leucosiidae & Ebalia пих & 2.9 & 1.4 & 2.2 & 0.4 \\
\hline & & & Ebalia tuberosa & 2.9 & 1.4 & 0.9 & 0.3 \\
\hline & & Xanthidae & Xantho granulicarpus & 2.9 & 1.4 & 0.9 & 0.3 \\
\hline & & & Monodaeus couchii & 2.9 & 1.4 & 0.7 & 0.3 \\
\hline & & & Non-identified Xanthidae & 7.1 & 3.4 & 1.4 & 1.5 \\
\hline & & Portunidae & Liocarniucus depurator & 2.9 & 1.4 & 0.2 & 0.2 \\
\hline & & & Liocarcinus corrugatus & 1.4 & 0.7 & 0.2 & 0.1 \\
\hline & & & Non-identified Portunidae & 2.9 & 1.4 & 0.3 & 0.2 \\
\hline & & Paguridae & Pagurus anachoretus & 4.3 & 2 & 0.6 & 0.5 \\
\hline & & & Paguristes eremita & 1.4 & 0.7 & 0.1 & + \\
\hline & & & Non-identified Paguridae & 2.9 & 1.4 & 0.8 & 0.3 \\
\hline & & Atelecyclidae & Atelecychus rotundatus & 1.4 & 0.7 & 0.1 & 0.1 \\
\hline & & Scyllaridae & Scyllarus arctus & 4.3 & 2 & 10.5 & 2.4 \\
\hline & & Majidae & Pisa nodipes & 1.4 & 0.7 & 1.9 & 0.2 \\
\hline & & & Non-identified Majidae & 1.4 & 0.7 & 0.6 & 0.1 \\
\hline & & Parthenopeidae & Non-identified Parthenopeidae & 1.4 & 0.7 & 0.4 & 0.1 \\
\hline Amphipoda & & & & 1.4 & 0.7 & 7.1 & 0.5 \\
\hline Isopoda & & & & 1.4 & 0.7 & 0.3 & 0.1 \\
\hline Non-identifi & Crustacea & & & 21.4 & 10.2 & 5.5 & 14.7 \\
\hline \multirow{19}{*}{\multicolumn{2}{|c|}{ Gastropoda }} & & & 32.9 & 28.6 & 9.1 & 14.2 \\
\hline & & Trochidae & Calliostoma zizyphinum & 1.4 & 0.7 & 0.3 & 0.1 \\
\hline & & & Calliostoma granulatum & 5.7 & 2.7 & 1.5 & 1.1 \\
\hline & & & Clanculus corallinus & 2.9 & 1.4 & 0.1 & 0.2 \\
\hline & & & Jujubinus corallinus & 4.3 & 2 & 0.4 & 0.5 \\
\hline & & & Jujubinus exasperatus & 4.3 & 2 & 0.3 & 0.4 \\
\hline & & Turbinidae & Astraea rugosa & 1.4 & 0.7 & + & + \\
\hline & & & Homalopoma sanguineum & 8.6 & 4.1 & 1.1 & 1.9 \\
\hline & & Buccinidae & Pisania leucozona & 1.4 & 0.7 & 0.1 & 0 \\
\hline & & Muricidae & Cerastoma erinaceum & 1.4 & 0.7 & 0.2 & 0.1 \\
\hline & & & Hadriania craticulata & 2.9 & 1.4 & 0.5 & 0.2 \\
\hline & & Coralliophilidae & Coralliophila sp. & 1.4 & 0.7 & 0.1 & + \\
\hline & & & Coralliophila meyendorffi & 1.4 & 0.7 & 0.1 & + \\
\hline & & Turritellidae & Turitella turbona & 7.1 & 3.4 & 2.2 & 1.8 \\
\hline & & Turridae & Comarmondia gracilis & 1.4 & 0.7 & + & + \\
\hline & & & Raphitoma reticulata & 1.4 & 0.7 & 0.5 & 0.1 \\
\hline & & & Mitrolumna olivoidea & 1.4 & 0.7 & 0.1 & + \\
\hline & & Rissoidae & Turbona cimex & 1.4 & 0.7 & + & + \\
\hline & & Cerithiidae & Bittium reticulatum & 1.4 & 0.7 & + & + \\
\hline Non-identifi & Gastropoda & & & 8.6 & 4.1 & 1.4 & 2.0 \\
\hline \multirow{3}{*}{\multicolumn{2}{|c|}{ Bivalvia }} & & & 7.1 & 3.4 & 0.8 & 0.3 \\
\hline & & Limidae & Lima hians & 4.3 & 2 & 0.6 & 0.5 \\
\hline & & Pectinidae & Palliolum incomparabile & 1.4 & 0.7 & 0.1 & + \\
\hline Non-identifi & Bivalvia & & & 1.4 & 0.7 & 0.2 & 0.1 \\
\hline Schaphopod & & & & 1.4 & 0.7 & + & + \\
\hline Non-identifi & Scaphopoda & & & 1.4 & 0.7 & + & + \\
\hline Pisces & & & & 28.6 & 13.6 & 35.3 & 16.1 \\
\hline Non-identifi & Pisces & & & 28.6 & 13.6 & 35.3 & 61.0 \\
\hline Echinoderm & & & & 4.3 & 3.4 & 2.2 & 0.3 \\
\hline Ophiuroidea & & & Ophiothrix fragiles & 1.4 & 2 & 0.7 & 0.2 \\
\hline Echinoidea & & & Parechinidae & 1.4 & 0.7 & 0.7 & 0.1 \\
\hline \multirow{3}{*}{\multicolumn{2}{|c|}{ Polychaeta }} & & & 1.4 & 0.7 & 0.8 & 0.1 \\
\hline & & & & 8.6 & 4.8 & 3.9 & 0.9 \\
\hline & & & Aphroditae & 7.1 & 3.4 & 3.2 & 2.0 \\
\hline Non-identifi & Polychaeta & & & 2.9 & 1.4 & 0.8 & 0.3 \\
\hline Rotatoria & 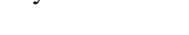 & & & 1.4 & 0.7 & 0.1 & + \\
\hline & & & Colurella adriatica & 1.4 & 0.7 & 0.1 & + \\
\hline Bryozoa & & & & 4.3 & 2.7 & 0.3 & 0.1 \\
\hline & & & Myriopora truncata & 1.4 & 0.7 & + & + \\
\hline & & & Micropora coriacea & 1.4 & 0.7 & + & + \\
\hline Non-identifi & Bryozoa & & & 2.9 & 1.4 & 0.2 & 0.2 \\
\hline Porifera & & & Spongidae & 1.4 & 0.7 & 0.1 & + \\
\hline Non-identifi & Spongidae & & & 1.4 & 0.7 & 0.1 & + \\
\hline Algae & & & & 2.9 & 1.4 & 0.1 & + \\
\hline Florideophy & & & Corallinaceae & 1.4 & 0.7 & 0.1 & + \\
\hline Phaeophyce & & & Halopteris filicina & 1.4 & 0.7 & + & + \\
\hline
\end{tabular}



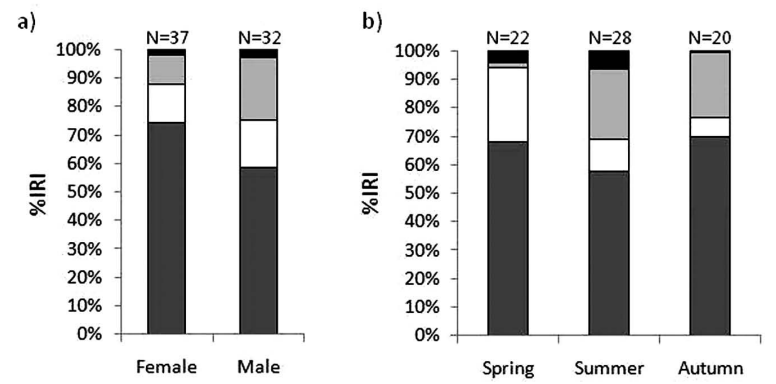

c)

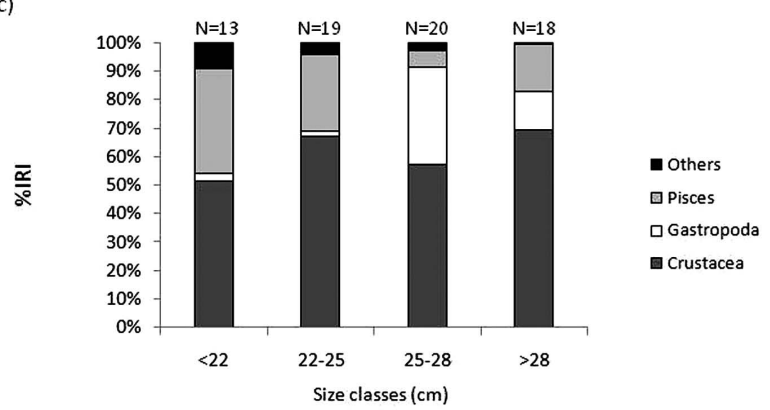

FIG. 10. - The diet composition of Labrus mixtus according to sex (A), season (B) and size (C) based on the index of relative importance (\%IRI) of the major prey groups. $\mathrm{N}$ is the number of analysed stomachs per group.

the smallest $(<22 \mathrm{~cm})$ and the largest $(>28 \mathrm{~cm})$ size classes. Crustaceans, gastropods and fishes, as the most frequent prey groups, are responsible for dietary differences between size classes. Figure 11 summarizes $\% \mathrm{~F}, \% \mathrm{~N}$ and $\% \mathrm{~W}$ for the principal prey categories. Crustaceans are predominant in both weight and number. Clearly, gastropods occur in larger number while fishes prevail in weight.

\section{DISCUSSION}

The cuckoo wrasse, Labrus mixtus, has no commercial value and is not among the most common labrid species in the recreational and artisanal fisheries in the Adriatic and Mediterranean Sea, such as the Mediterranean rainbow wrasse Coris julis (Škeljo et al. 2012). However, these fisheries in the Mediterranean and Adriatic coastal area are developing intensively (EU 2004) and exert increasing pressure on fish populations (Morales-Nin et al. 2005, Cardona et al. 2007, Lloret et al. 2008). Therefore, more authors consider that they can significantly affect the populations of harvested species and should be taken into account in the management and conservation (Covx 2002 and papers therein). The number of recreational fishers is usually high, leading to high levels of fishing effort (Cowx 2002, Pitcher and Hollingworth 2002, Westera et al. 2003), which for some species may be higher than in the commercial fisheries (Pollock 1980, Beal et al. 1998).

The length range of sampled Labrus mixtus was 13.0 to $38.2 \mathrm{~cm}$ and the maximum length of $40 \mathrm{~cm}$ was previously reported by Bauchot (1987). Although we were forced to use several different fishing tech-

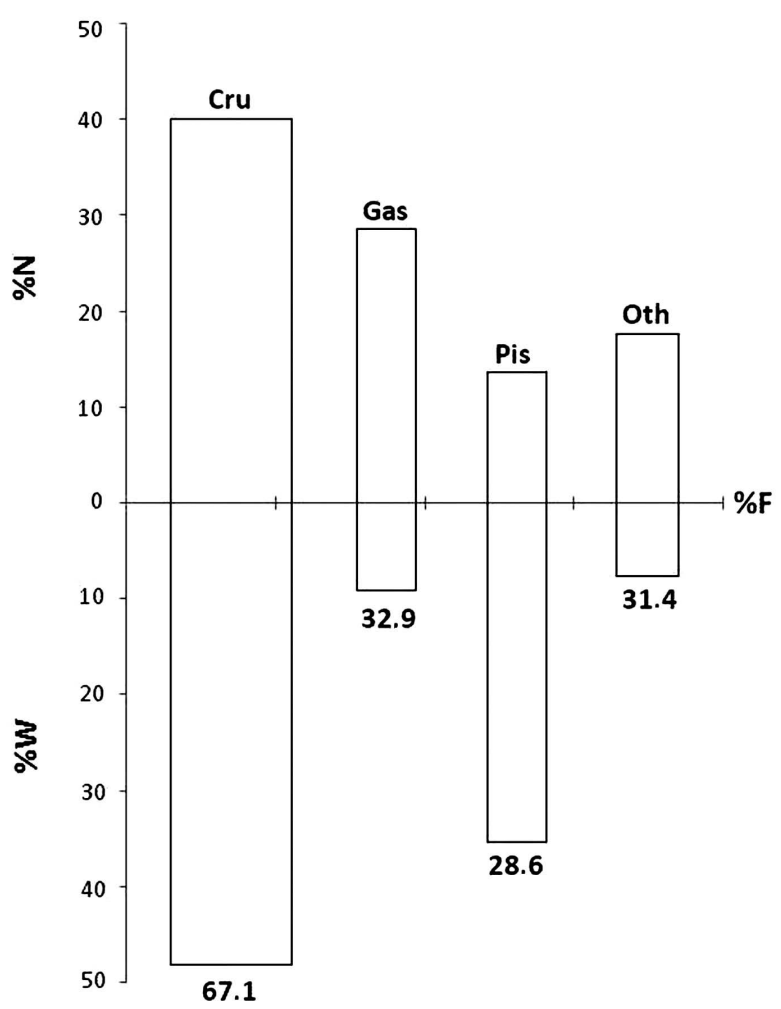

FIG. 11. - The frequency of occurrence $(\% \mathrm{~F})$, percent number $(\% \mathrm{~N})$ and weight $(\% \mathrm{~W})$ for the major prey groups in the diet of Labrus mixtus from the central Adriatic Sea: Cru, crustaceans; Gas, gastropods; Pis, fishes; Oth, others.

niques in order to collect a representative sample, smaller specimens are missing because of fishing gear selectivity and the depth ranges inhabited by this species (Dulčić et al. 2004). Specifically, the specimens captured by angling fishing tools are dominated by medium and large pieces, while the size of the hook prevented catch of the smallest individuals. Most of the sample was collected from the commercial trammel nets, which have certain selectivity according to their mesh size. Also, specimens were not caught during winter months because opportunities for fishing were rare due to bad weather, but it is possible that this species retreats deeper or completely reduces its activity during winter and therefore catchability decreases drastically.

The results showed that Labrus mixtus is a protogynous hermaphrodite, as previously determined by Dipper and Pullin (1979). Both females and males of L. mixtus have been captured in the Adriatic coastal waters at depths of around 30-65 m. Although females were numerous in the sample, they did not significantly dominate in the total sex ratio. Female predominance is characteristic for protogynous hermaphroditism because territorial males with their aggressive dominance limit production of other males (Sandovy and Shapiro 1987). The evolution of sex change is explained by the model, which predicts that sex change will be more ef- 
fective if the reproductive success increases with age or size at a higher rate in one sex than the other (Warner 1975). While female reproductive success does not depend so much on their size, larger males have significantly higher reproductive success than smaller ones.

Labrus mixtus as a female reaches sexual maturity at $16 \mathrm{~cm}$ in length and 2 years of age (Jardas et al. 2008). The specimens below $16 \mathrm{~cm}$ in total length were females and accounted for $2.7 \%$ of the total number of females in the sample. The size at which $L$. mixtus begins to change sex is about $26 \mathrm{~cm}$. It seems that sex change is always more closely related to size than age, as are maturity and fecundity (Jones 1980). Analysis of gonadosomatic index showed that L. mixtus spawn once a year in spring, with a peak in April. These findings are in agreement with previously published results (Quingard and Pras 1986, Jardas et al. 2008). Sex change in labrids species is often accompanied by changes of body colouration, so they are sexually dichromatic (Coulson et al. 2009). Females prefer to mate with more intensely coloured males, as such colouration may indicate higher-quality males (Robertson 1972). As a consequence, sexual dichromatism will increase the reproductive success of larger males compared with smaller ones (Kazancioglu and Alonzo 2010).

There is a lack of age data for the most species of the Labridae family, and in this study we decided to use otoliths, since they are the most frequently used hard part for fish ageing (Sparre and Venema 1992). Labrus mixtus otoliths exhibited a well-defined and consistent mark pattern consisting of one opaque and one translucent zone. The present results showed that growth zones in otoliths of $L$. mixtus are laid down annually, the opaque zone being generally deposited in summer, just after the observed spawning period, and the translucent zone in the autumn-winter period. In general, otoliths of L. mixtus were determined to be valid structures for age and growth studies due to the great consistency among repeated age readings. However, a problem of the right growth zone recognition, especially in older individuals, occurred during age reading. The first hyaline ring, which occurs in the early autumn, coincides with time of settlement (Gordoa et al. 2000). It seems that its formation indicates biological or physiological changes in the individuals rather than seasonal changes in environmental factors. The same finding was recognized for $L$. mixtus in the Adriatic Sea, with the only difference in the prolonged deposition period for formation of both rings. Munday et al. (2004) reported the presence of a sex-specific growth effect of protogynous parrotfishes, in which otoliths of fast-growing individuals (males) are smaller than otoliths of slow-growing individuals (females). The sex-specific growth effect was most pronounced during the early life history, suggesting that only the fastest-growing females change sex to male (Munday et al. 2004). These results demonstrate that the relationship between otolith and somatic growth can vary dramatically between the sexes. This will make it difficult to back-calculate size at age in protogynous species, unless the precise relationship between otolith and somatic growth is known for each sex.

Population estimates for all specimens of L. mixtus from the Adriatic Sea gave results of $\mathrm{L}_{\infty}=34.2 \mathrm{~cm}$, $\mathrm{k}=0.224 \mathrm{yr}^{-}$and $\mathrm{t}_{0}=-0.438 \mathrm{yr}$. The obtained asymptotic length is lower than the maximum length observed in sampled individuals. The first years of life are probably overestimated because smaller specimens are deficient as a result of fishing gear selectivity. Also, males grow at a slightly higher rate than females. This finding was also observed for protogynous parrotfishes (Munday et al. 2004). Unfortunately, no published data on growth of L. mixtus or close relatives were available for comparison. It seems that this species has relatively fast growth in first years before sex change and after that growth slows down. Although there were no significant differences for any of the age classes in the mean lengths at age between sexes of L. mixtus, the age frequency distributions of males and females differed significantly. Choat et al. (1996) reported that protogynous males of the family Scaridae dominated the older age classes and males were consistently larger than females for a given age class. Also, although both sexes exhibited positive allometric growth, the $b$ was significantly higher for males, indicating that males grow faster in weight than females. A similar finding was reported by Mendes et al. (2004) for L. mixtus of the Portuguese west coast. Gordoa et al. (2000) found that a close relative species Labrus merula, also exhibits positive allometric growth on the northwestern Mediterranean coast. However, population density, water temperature and the quantity of available food could undoubtedly affect growth of $L$. mixtus in both females and males. The oldest sampled L. mixtus specimens were 10 year-old-males. We suppose that their life span could be around 15 years, which can be supported by the estimated longevity values of 13 years. Nevertheless, longevity is a theoretical value based on parameters obtained by VBGF and is very sensitive to the sample, so it may be far from the reality. Our VBGF estimates appear realistic values since the maximal total length for the L. mixtus in the Adriatic Sea is up to $40 \mathrm{~cm}$ (Jardas 1996).

The Labridae family may be considered as mesophagic carnivores (Bell and Harmelin-Vivien 1982) feeding on copepods, gammarid amphipods, decapods, ostracods and other crustaceans, as well as molluscs. Wrasse species are crusher feeders (Gerking 1994) with well-developed physical adjustments that include strong teeth in the jaws (for biting and rasping) and on the pharyngeal bones in the throat (for gripping and crushing), which allow them to break the hard shell invertebrates (Liem and Sanderson 1986). Labrus mixtus is an obligatory carnivorous feeder whose diet in the Adriatic Sea is primarily based on crustaceans and gastropods, but also on small fishes, polychaetes, bivalves and echinoderms. Crustaceans and gastropods combined represented $68.7 \%$ of the diet and occurred 
in $>70 \%$ of the fish. Taking further into account bivalves, echinoderms and bryozoans, the preference for hard-bodied prey is evident. This finding is also supported by the structure of the mouth and gut: $L$. mixtus, like other wrasses, has a pharyngeal jaw. The high proportion of unidentified hard-bodied prey $(30 \%$ of the specimens) is probably related to their feeding behaviour, which involves ripping parts of prey bodies (Graham 1956), so they become impossible to identify. Although morphological characteristics can greatly influence prey selection, the most important factors are usually size and availability (Moyle and Cech 2000). Thus, most prey species are also common representatives of Adriatic infralittoral and circumlittoral fauna that inhabit different types of bottoms, particularly detritic ones. The aforementioned, together with the fact that no prey species is particularly dominant, indicates that feeding of L. mixtus is much more opportunistic than selective.

A higher level of diversity in diet is noted for males, and also in early summer. Perhaps this can be explained by the fact that males, which are territorial during and after the spawning season, defend an area in which the spawning take place and the eggs are laid. These activities may affect the dietary preferences, so males become even more opportunistic and eat wider variety of food organisms within the restricted area (Šoljan 1968). Similar observation was previously reported for close relative species Labrus merula (Dulčić 1999).

Feeding intensity can be explained with the vacuity index, with which it is negatively related to (Bowman and Bowman 1980). Spawning period seems to have an effect on feeding intensity. Feeding behaviour of most fish species varies considerably during the year as a consequence of physiological changes during reproduction. In our study the data indicate that $L$. mixtus feeds least intensively during spawning, as is shown by the higher \%VI from April to June. Jardas and Pallaoro (1991) found that feeding intensity of Scropaena porcus showed markedly lower values during spawning. This is similar to the case of Chromis chromis (Dulčić 1996) and Trachurus trachurus (Jardas et al. 2004) from the Adriatic Sea.

In conclusion, more information about population structure and distribution of L. mixtus in the Mediterranean and the Adriatic Sea is needed in order to improve the scientific knowledge about this species. Fisheries can negatively affect littoral fishes, especially ones showing a complicated reproductive strategy. This is exactly the case with sex-changing fish species, particularly the protogynous ones, such as L. mixtus and its close relatives L. merula and Labrus viridis, and the species with complex mating systems (e.g. some sparids, labrids and scorpaenids) (Lloret et al. 2012). Therefore, management of artisanal and recreational fishing requires stronger enforcement of existing regulatory measures and/or additional regulations such as the restricted and closed areas. Thus, new management actions need to be urgently implemented in the coastal area where those fisheries are allowed to operate, taking care not only of target species but also of by-catch and discard in order to protect these littoral Mediterranean fish species.

\section{ACKNOWLEDGEMENTS}

We thank all local fishers involved in the collection of material, especially Mate Šiljić, Damir Karuza and Dina Belanić. The work was supported by the Ministry of Science, Education and Sport, Croatia through projects 001-0013077-0844.

\section{REFERENCES}

Bauchot M.L. 1987. Poissons osseux. In: Fischer W., Bauchot M.L., Schneider M. (eds), Fiches FAO d'identification pour les besoins de la pêche. Méditerranée et mer Noire, (Vol. II). Rome, Commission des Communautés Européennes and FAO, pp. 891-1421.

Beal R.E., Desfosse J.C., Field J.D., Schick A.M. 1998. Special report No. 66 of the Atlantic States Marine Fisheries Commission. 1998 Annual Review of Interstate Fishery Management Plans. Atlantic States Marine Fisheries Commission (ASMFC), Washington DC, $73 \mathrm{pp}$.

Beamish R.J., Fournier D.A. 1981. A method for comparing the precision of a set of age determination. Can. J. Fish. Aquat. Sc. 38: 982-983.

Bell J.D., Harmelin-Vivien M.L. 1982. Fish fauna of French Mediterranean Posidonia oceanica seagrass meadows. II. Feeding habits. Tethys 11: 1-14.

Beverton R.J.H., Holt S.J. 1957. On the dynamics of exploited fish populations. Fishery Investigations Series II, (Vol. XIX). Ministry of Agriculture, Fishery and Food, Great Britain. 533 pp.

Bowman R.E., Bowman E.W. 1980. Diurnal variation in the feeding intensity and catchability of silver hake (Merluccius bilinearis). Can. J. Fish. Aquat. Sc. 37: 1565-1572.

Cardinale M., Colloca F., Ardizzone G.D. 1998. Growth and reproduction of Xyrichthys novacula (Pisces: Labridae) in the Mediterranean Sea. Sci. Mar. 62:193-201.

Cardona L., López D., Sales M., Caralt S., Díez I. 2007. Effects of recreational fishing on three fish species from the Posidonia oceanica meadows off Minorca (Balearic archipelago, western Mediterranean). Sci. Mar. 71: 811-820.

Cetinić P., Škeljo F., Ferri J. 2011. Discards of the commercial boat seine fisheries on Posidonia oceanica beds in the eastern Adriatic Sea. Sci. Mar. 75: 289-300.

Chang W.B. 1982. A statistical method for evaluating the reproducibility of age determinations. Can. J. Fish. Aquat. Sc. 39: 1208-1210.

Choat J.H., Axe L.M., Lou D.C. 1996. Growth and longevity in fishes of the family Scaridae. Mar. Ecol. Prog. Ser. 145: 33-41.

Choat H., Bellwood D. 1998. Wrasses and Parrot-fishes. In: Eschemeyer W.N., Paxton J.R. (eds), Encyclopedia of fishes, Second edition. San Diego, CA, Academic press, pp. 209-213.

Clarke K.R., Warwick R.M. 2001. Change in marine communities: an approach to statistical analysis and interpretation. 2nd edition. PRIMER-E, Plymouth.

Coleman F., Figueira W.F., Ueland J.S., Crowder L.B. 2004. The impact of United States recreational fisheries on marine fish populations. Science 305: 1958-1959.

Coulson P.G., Hesp S.A., Hall N.G., Potter I.C. 2009. The western blue groper (Achoerodus gouldii), a protogynous hermaphroditic labrid with exceptional longevity, late maturity, slow growth, and both late maturation and sex change. Fish. B-NOAA. 107: 57-75.

Cowx I.G. 2002. Recreational fishing. In: Hart P., Reynolds J.D. (eds), Handbook of Fish Biology and Fisheries, Vol. II. Oxford, Blackwell Science, pp. 367-390.

Dipper F.A., Pullin R.S.V. 1979. Gonochorism and sex-inversion in British Labridae (Pisces). J. Zool. 187: 97-112.

Dulčić J. 1996. Food and feeding habits of the damselfish Chromis 
chromis (Teleostei: Pomacentridae) in the eastern Adriatic. Annales for Istrian and Mediterranean studies 9: 31-36.

Dulčić J. 1999. The diet of the brown wrasse Labrus merula (Labridae) in the eastern Adriatic. Cybium 23: 381-389.

Dulčić J., Fencil M., Matić-Skoko S., Kraljević M., Glamuzina B. 2004. Diel catch variations in a shallow-water fish assemblage at Duće-Glava, eastern Adriatic (Croatian coast). J. Mar. Biol. Assoc. UK 84: 659-664.

EU 2004. Mediterranean: guaranteeing sustainable fisheries. Fishing in Europe 21: 1-12.

Gerking S.D. 1994. Feeding Ecology of fish. New York, Academic Press, $326 \mathrm{pp}$

Gomon M.F., Forsyth P. 1990. Labridae. In: Quero J.C., Hureau J.C., Karrer C., Post A., Saldanha L. (eds), Check-list of the fishes of the eastern tropical Atlantic (CLOFETA), Vol. 2 JNICT, Lisbon, SEI, Paris, Paris and UNESCO, pp. 868-882.

Gordoa A., Molí B., Raventós N. 2000. Growth performance of four wrasse species on the north-western Mediterranean coast. Fish. Res. 45: 43-50.

Graham D.H. 1956. A treasury of New Zealand fishes, 2nd ed. New Zeland, Wellington, $264 \mathrm{pp}$.

Giudetti P. 2000. Differences among fish assemblages associated with nearshore Posidonia oceanica sea grass beds, rocky algalreefs and unvegetated sand habitats in the Adriatic Sea. Estuar. Coast. Shelf Sci. 50: 515-529.

Hyslop E.J. 1980. Stomach content analysis: a review of methods and their application. J. Fish Biol. 17: 411-429.

Jardas I. 1996. Jadranska ihtiofauna. Zagreb, Školska knjiga, 293 pp.

Jardas I., Pallaoro A. 1991. Food and feeding habits of black scorpionfish (Scorpaena porcus L., 1758) (Pisces: Scorpaenidae) along the Adriatic coast. Acta Adriat. 32: 885-898.

Jardas I., Pallaoro A., Vrgoč N., Jukić-Peladić S., Dadić V. 2008. Crvena knjiga morskih riba Hrvatske. Republika Hrvatska, Ministarstvo kulture, Državni zavod za zaštitu prirode, 396 pp.

Jardas I., Santić M., Pallaoro A. 2004. Diet composition and feeding intensity of horse mackerel, Trachurus trachurus (Osteichthyes: Carangidae) in the eastern Adriatic. Mar. Biol. 144: 1051-1056.

Jones G.P. 1980. Growth and reproduction in the protogynous hermaphrodite Pseudolabrus celidotus (Pisces: Labridae) in New Zealand. Copeia 4: 660-675.

Kazancioglu E., Alonzo S.H. 2010. A comparative analysis of sex change in labridae supports the size advantage hypothesis. Evolution 64: 2254-2264.

Liem K.F., Sanderson S.L. 1986. The pharyngeal jaw apparatus of labrid fishes: a functional morphological perspective. J. Morphol. 187: 143-158.

Lloret J., Zaragoza N., Caballero D., Riera V. 2008. Biological and socioeconomic implications of recreational boat fishing for the management of fishery resources in the marine reserve of Cap de Creus (NW Mediterranean). Fish. Res. 91: 252-259.

Lloret J., Muñoz M., Casadevall M. 2012. Threats posed by artisanal fisheries to the reproduction of coastal fish species in a Mediterranean marine protected area. Estuar. Coast. Shelf Sci. 113: 133-140.

Mendes B., Fonseca P., Campos A. 2004. Weight-length relationships for 46 fish species of the Portugese west coast. J. Applied Ichthyol. 20: 355-361

Moe M.A. Jr. 1969. Biology of the red grouper (Epinephelus morio Velenciennes) from the eastern Gulf of Mexico. Florida Department of Natural Resources Marine Research Laboratory, Professional Paper 10: 1-95.

Morales-Nin B., Moranta J., García C., Tugores M.P., Grau A.M Riera F., Cerdà M. 2005. The recreational fishery off Majorca Island (western Mediterranean): some implications for coastal resource management. ICES J. Mar. Sci. 62: 727-739.

Moyle P., Cech J. 2000. Fishes: An Introduction to Ichthyology. 4th edn. Upper Saddle River, NJ, Prentice Hall, 559 pp.

Munday P.L., Hodges A.L., Choat J.H., Gust N. 2004. Sex-specific growth effects in protogynous hermaphrodites. Can. J. Fish. Aquat. Sc. 61: 1-323.

Muus B.J., Nielsen J.G. 1999. Sea fish. Scandinavian Fishing Year Book. Denmark, Hedehusene, $340 \mathrm{pp}$.

Nelson J. 1994. Fishes of the World. 3rd edn. NY, New York, John
Wiley and Sons, $600 \mathrm{pp}$.

Pallaoro A., Jardas I. 2003. Some biological parameters of peacock wrasse, Symphodus (Crenilabrus) tinca (L. 1758) (Pisces: Labridae) from the middle eastern Adriatic (Croatian coast). Sci. Mar. 67: 33-41.

Palazón-Fernandez J.L., Potts J.C., Manooch C.S.III, Sarasquete C. 2010. Age, growth and mortality of the toadfish, Halobatrachus didactylus (Schneider, 1801) (Pisces: Batrachoididae), in the Bay of Cádiz (southwestern Spain). Sci. Mar. 74: 121-130.

Pauly D., Christensen V., Guénette S., Pitcher T.J., Sumaila U.R., Walters C.J., Watson R., Zeller D. 2002. Towards sustainability in world fisheries. Nature 418: 689-695.

Pinkas L., Oliphant M.S., Iverson I.L.K. 1971. Food habits of albacore, bluefin tuna and bonito in California waters. Fish. Bull. 152: $1-105$

Pollock B. 1980. Surprises in Queensland angling study. Australian Fish. 39: 17-19.

Pitcher T.J., Hollingworth C.E. 2002. Recreational Fisheries: Ecological, Economic and Social Evaluation. England, Oxford, Fish and Aquatic Resources Series 8. Blackwell Science, $225 \mathrm{pp}$.

Quignard J.P., Pras A. 1986. Labridae. In: Whitehead P.J.P., Bauchot M.L., Hureau J.C., Nielsen J., Tortonese E. (eds), Fishes of the north-eastern Atlantic and the Mediterranean, Vol. 2. Paris, UNESCO, pp. 919-942.

Ricker W.E. 1975. Computation and interpretation of biological statistics of fish populations. B. Fish. Res. Board Can. 191: 1-382.

Robertson D.R. 1972. Social control of sex reversal in a coral reef fish. Science 177: 1007-1009.

Saila S.B., Recksiek C.W., Praguer H. 1988. Basic Fishery Science Programs. A compendium of Microcomputer Programs and Manual of Operation. Dev. Aquacult. Fish Sci. 18: 1-230.

Sandovy Y., Shapiro D.Y. 1987. Criteria for the diagnosis of hermaphroditism in fishes. Copeia 1: 136-156.

Smith C.L. 1965. The patterns of sexuality and the classification of serranid fishes. Am. Mus. Novit. 2207: 1-20.

Sparre P., Venema S.C. 1992. Introduction to tropical fish stock assessment. Part 1. FAO Fisheries Technical Paper, Rome, Food and Agriculture Organization, $376 \mathrm{pp}$.

Stagličić N., Matić-Skoko S., Pallaoro A., Grgičević R., Kraljević M., Tutman P., Dragičević B., Dulčić J. 2011. Long term trends in the structure of eastern Adriatic littoral fish assemblages: Consequences for fisheries management. Estuar. Coast. Shelf Sci. 94: 263-271.

Šoljan T. 1968. Fish parental adaptation in nest taking care. Bilten Biološkog društva SR BiH 56: 1-155.

Škeljo F., Ferri J., Brčić J., Petrić M., Jardas I. 2012. Age, growth and utility of otolith morphometrics as a predictor of age in the wrasse Coris julis (Labridae) from the eastern Adriatic Sea. Sci. Mar. 76: 587-595.

Taylor C.C. 1960. Temperature, growth and mortality - the Pacific cockle. J. Conseil 26: 117-124.

Tsikliras A.C., Stergiou K.I., Froese R. 2013. Editorial note on reproductive biology of fishes. Acta Ichthyol. Piscat. 43 (1): 1-5.

Tzanatos E., Somarakis S., Tserpes G., Koutsikopoulos C. 2007. Discarding practices in a Mediterranean small-scale fishing fleet (Patraikos Gulf, Greece). Fisheries Manag. Ecol. 14: 277-285.

Wainwright P., Bellwood D. 2002. Ecomorphology of feeding in Coral Reef Fishes. In: Sale P. (ed.), Coral Reef Fishes: Dynamic and Diversity in a Complex Ecosystem. CA, San Diego, Academic Press, pp 33-35.

Warner R.R. 1975. Adaptive significance of sequential hermaphroditism in animals. Am. Nat. 109: 61-82.

Warner R.R., Lejeune P. 1985. Sex change limited by paternal care: a test using for Mediterranean labrid fishes, genus Symphodus. Mar. Biol. 87: 89-99.

Westera M., Lavery P., Hyndes G. 2003. Differences in recreationally targeted fishes between protected and fished areas of a coral reef marine park. J. Exp. Mar. Biol. Ecol. 294: 145-168.

Scient. ed.: A. Garcia-Rubies.

Received May 8, 2013. Accepted October 3, 2013.

Published online November 7, 2013. 